\title{
К ВОПРОСУ О ПОВЫШЕНИИ КОМПЕТЕНТНОСТИ ПРОФЕССОРСКО-ПРЕПОДАВАТЕЛЬСКОГО СОСТАВА ОБРАЗОВАТЕЛЬНЫХ ОРГАНИЗАЦИЙ СИСТЕМЫ МВД РОССИИ
}

\section{THE QUESTION OF IMPROVING THE COMPETENCES OF THE FACULTY OF EDUCATIONAL ORGANIZATIONS OF THE SYSTEM OF THE MINISTRY OF THE RUSSIAN FEDERATION}

\section{Korotaeva}

Summary: The article presents a professional image of a modern teacher of the high school. The peculiarities of his multifaceted professional activity are revealed: scientific, methodical, educational. The emphasis is on the peculiarities of the activities of teachers of the higher school and the work of teachers in the system of the Ministry of Internal Affairs of Russia. The problem of competences and professional teaching position is detailed. The basic requirements for teachers of higher education, teacher characteristics and responsibilities at the current stage of education development are considered, as well as the main tasks facing teachers of the higher education.

Keywords: teaching staff of the higher education, competences, teachers in educational organizations of the system of the Ministry of Internal Affairs of Russia, methods of pedagogical interaction, professional and pedagogical position, police officer.

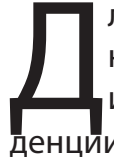
ля современного образования понимание личности обучающегося и преподавателя, сущности их взаимодействия является приоритетным. Тенв педагогике находят свое закономерное подтверждение в нормативно-правовых актах, регламентирующих данную сферу деятельности. В законе «Об образовании» (статья 3) выделены основные принципы государственной политики и правового регулирования отношений в сфере образования:

1. значимость и необходимость образования;

2. обеспечение права каждого человека на образование;

3. гуманистический характер образования;

4. единство образовательного пространства на территории Российской Федерации;

5. создание благоприятных условий для интеграции системы образования Российской Федерации с системами образования других государств;

6. светский характер образования;

7. свобода выбора получения образования;

8. независимость образовательных организаций;
Коротаева Мария Сергеевна

Преподаватель, Дальневосточный юридический институт МВД России, г. Хабаровск

musakor@mail.ru

Аннотация: В статье представлен профессиональный образ современного преподавателя высшей школы. Раскрываются особенности его многогранной профессиональной деятельности: научной, методической, учебной и воспитательной. Сделан акцент на особенности деятельности преподавателей высшей школы и работы преподавателей в системе МВД России. Освещается проблема компетентности и профессионально-педагогической позиции. Рассматриваются основные требования к преподавателям высшей школы, характеристики преподавателя и его обязанности на современном этапе развития образования, а также основные задачи, стоящие перед педагогами высшей школы.

Ключевые слова: профессорско-преподавательский состав высшей школы, компетентность, преподаватели в образовательных организациях системы МВД России, способы педагогического взаимодействия, профессиональнопедагогическая позиция, сотрудник органов внутренних дел.

9. демократический характер управления образованием;

10. недопустимость ограничения конкуренции в сфере образования;

11. сочетание государственного и договорного регулирования отношений в сфере образования [1].

Одной из основных задач в деятельности преподавателя является, с одной стороны, способствовать формированию высококвалифицированного специалиста, а с другой - развитию личности обучающегося. Указанное характерно для педагогических работников в целом, независимо от специфики образовательной организации. При этом, помимо компетенций, которыми должны обладать все преподаватели высших учебных заведений, педагогическим работникам необходимо владеть дополнительными профессиональными умениями и навыками для формирования специалиста в конкретной сфере деятельности. Так, например, для воспитания и обучения будущих сотрудников полиции преподаватели в образовательных организациях системы МВД России 
должны обладать необходимыми компетенциями и профессионально-личностными качествами как сотрудника полиции, так и педагога. Осмысливая это, можно прийти к выводу, что начинающий педагогическую деятельность сотрудник, не имеющий соответственного образования или наоборот, когда педагогическое образование есть, а знание специфики службы в правоохранительных органах предполагает то, что педагогический работник не в полной мере обладает достаточными компетенциями.

Ответственность перед государством и обществом за свою профессиональную деятельность присутствует у выпускников всех образовательных организаций. Особенно в образовательных организациях системы МВД России эти задачи дополняются еще и пониманием службы Отечеству. Так, в законе «О полиции», уже в Главе 1 сказано: «Полиция предназначена для защиты жизни, здоровья, прав и свобод граждан Российской Федерации, для противодействия преступности, охраны общественного порядка, собственности и для обеспечения общественной безопасности» [2].

Будучи специалистами в своей профессиональной деятельности - следователя, оперативника, юриста, педагогического работника и др., преподаватели вузов системы МВД оказываются недостаточно подготовленными к своей профессионально-педагогической деятельности. Именно поэтому, применяемые преподавателями способы педагогического взаимодействия нередко оказываются недостаточно результативными.

Рост технического прогресса, развитие цифровых технологий влияют на систему образования и определяют задачи модернизации в целом. Внедрение инновационных технологий и компьютеризация образования подтолкнули преподавателей высшей школы к пересмотру устоявшихся теоретических и практических аспектов обучения, традиционных подходов к учебновоспитательной деятельности, в том числе и в системе МВД России. Возникла объективная потребность в компетентных кадрах - педагогах-профессионалах, которые могут «творчески организовать учебный процесс, легко адаптируются в стремительно меняющемся информационном пространстве, способны непрерывно самосовершенствоваться» [3].

Развитие образования делает всё более актуальным решение проблемы оценки профессионализма преподавателей, сформированности профессионально-педагогической позиции, которая определяет траекторию профессионального развития педагога.

В научных трудах О.Л. Берак, А.В. Мудрика, 3.А. Несимовой педагогическая деятельность определяется как личностное образование, выражающее профессиональную позицию каждого конкретного педагога, что проявляется в профессиональных компетенциях [4]. По мнению Д.А. Иванова, К.Г. Митрофанова, О.В. Соколовой, поводом для разработки компетентностного подхода является несоответствие содержания образования потребностям современной социально-экономической системы [5].

Важно отметить, что, говоря о профессиональной позиции преподавателя, чаще всего имеют в виду именно педагогическую позицию. По нашему мнению, это можно объяснить тем обстоятельством, что именно для педагогической деятельности позиция является своего рода фундаментом профессиональной деятельности. Без чётко сформулированной и личностно значимой профессиональной позиции педагога его деятельность утрачивает свои важные сущностные характеристики.

В научной литературе профессиональная позиция преподавателя высшей школы рассматривается как «неотъемлемая составляющая профессиональной компетентности и необходимое условие осуществления педагогической деятельности» (В.И. Бедерханова, И.А. Колесникова, С.И. Краснов, А.К. Маркова, В.И. Слободчиков, Г.А. Цукерман и др.) [6]. Педагог, обладающий соответствующей профессиональной позицией, призван помочь учащемуся раскрыть все стороны его индивидуальности.

В педагогике высшей школы данный феномен приобретает еще большее значение, так как включает еще и сформированное отношение к профессии, которой владеет специалист, когда приходит в сферу профессионального образования, и у него стоит задача не только донести знания относительно своей профессии, но и сформировать отношение к этой профессии у обучающегося.

В процессе теоретического исследования и анализа можно выделить феномен профессионально-педагогической позиции преподавателя высшей школы в системе МВД России как профессионально-личностное качество, которое базируется на развитии ценностно-смысловых отношений к педагогической профессии, к служебной деятельности и определяет стиль преподавания, а также осознание себя как образец сотрудника органа внутренних дел для курсантов и слушателей.

Объединяя и анализируя приведенные мнения, выстраивается структура профессиональной компетентности, которую можно раскрыть следующим образом (таблица 1).

Исходя из изложенного выше, профессиональная компетентность понимается как система специальных знаний, умений и навыков, включая опыт выполнения профессиональных действий и систему личных качеств [7]. 
Таблица 1.

Содержание структуры профессиональной компетентности

\begin{tabular}{|l|l|l|}
\multicolumn{1}{|c|}{ Мобильность знаний } & \multicolumn{1}{|c|}{ Вариативность метода } & \multicolumn{1}{c|}{ Критичность мышления } \\
\hline - подготовленность к самостоятельному & - умение решать типовые профессиональные & - умение оценивать результаты своего труда \\
эффективному выполнению конкретных видов & задачи & - способность к профессиональной рефлексии \\
деятельности & - готовность к реализации себя в профессио- & - умение успешно осваивать новое и быстро \\
- желание самосовер- шенствоваться & нальном труде & адаптироваться к изменяющимся условиям \\
- высокий уровень успешности взаимодействия & - профессионально-технологическая подготов- & - способность брать на себя ответственность и \\
с обществом и окружающей средой & ленность & принимать решения, работать в команде \\
- готовность к постоянному повышению квали- \\
фикации & - способность качественно и безошибочно вы- & - гибкость появляющихся требований и измене- \\
& полнять свои функции в обычных и экстремаль- & ний, выносливость и целеустремленность \\
& ных условиях & \\
\hline
\end{tabular}

Структура деятельности профессорско-преподавательского состава высшей школы

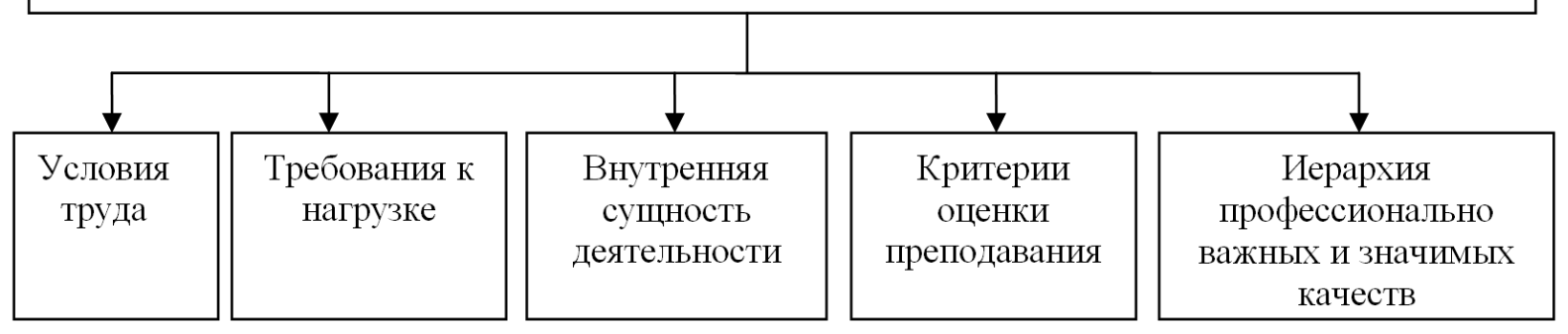

Рис. 1. Структура специфики деятельности профессорско-преподавательского состава высшей школы

Приведенный анализ показывает различные подходы к понимаю профессиональных компетентностей, выделяя разные направления, в основе которых лежит выделение организаторских (специальная) и коммуникативных (личностных), как направлений, обеспечивающих решение технологических и образовательных задач.

Анализ современного состояния развития высшего образования выделяет компетентностный подход как наиболее соответствующий тенденциям развития технического, экономического и социального прогресса. Это обуславливает то, что компетентности становятся критериями оценки качества образования и эффективности профессиональной деятельности профессорско-преподавательского состава.

Таким образом, оценка качества и эффективности профессиональной деятельности преподавателей образовательных организаций системы МВД России опирается на компетенции и компетентности и выделяет для последующего анализа понимание, что:

- «компетенция» рассматривается как совокупность знаний, их использование и применение в профессиональной деятельности;

- «компетентность» как личностное свойство, основывающееся на знаниях, интеллекте, выражающееся непосредственно в его поведении в социуме;
- в основе компетентностного подхода образовательного процесса лежат компетентности специалиста, формирование которых - цель и результат образования [8].

Оценка результативности профессиональных компетенций профессорско-преподавательского состава опирается на общие подходы понимания профессиональных компетентностей через оценку нового опыта, ключевыми компонентами которого являются актуализация, обновление, воплощение личностных смыслов профессиональной деятельности, напрямую связанных с реализацией педагогических компетентностей: коммуникативных и организационных.

Среди многообразия подходов к анализу деятельности преподавателей высшей школы, осуществляющих работу с аудиторией, на сегодняшний день компетентностный подход можно считать одним из наиболее прогрессивных.

В его основе лежит понятие структуры специфики деятельности (рисунок 1).

Существует ряд особенностей трудовой деятельности преподавателей и в системе высшего образования МВД России. Так основной профессорско-преподавательский состав - сотрудники органов внутренних дел, что оказывает влияние на требования к компетенциям и 
оценку результатов их деятельности.

В соответствии с Федеральным законом «Об образовании» от 29 декабря 2012 г. № 273-Ф3 к компетенции преподавателя высшей школы наряду с другими компонентами относятся: «реализация обучения в соответствии с ФГОС и компетентностным подходом, эффективная организация самостоятельной работы обучающихся, знание и использование новых образовательных технологий, содействие развитию личности, воспитанию и формированию культуры обучающихся, развитие опыта их творческой и познавательной деятельности» [1]. Таким образом, преподаватель должен не только обладать теоретической базой и практическим опытом, но и уметь заинтересовать аудиторию, мотивировать к изучению своего предмета.

Преподаватель подобно священнику, не может позволить себе быть безнравственным, «плохим» духовно. Он должен осознавать, что является примером для курсантов, образом идеального сотрудника, качества профессионала, не только как педагога, но и как полицейского. Курсанты впитывают не только знания по конкретной дисциплине, но и наблюдают за его нравственной оценкой действительности, поведением, успехами на службе. Преподаватель в системе МВД России должен понимать, что является примером и внешне, и внутренне, передавая не только теоретический материал и практический опыт, но и нравственные принципы, и идеалы, мировоззрение и нормы этики.

\section{ЛИТЕРАТУРА}

1. Федеральный закон от 29.12.2012 № 273-Ф3 (ред. от 08.12.2020) "0б образовании в Российской Федерации" (с изм. и доп., вступ. в силу с 01.01.2021).

2. Федеральный закон РФ «0 полиции» № 3-Ф3 от 07.02.2011 гл.1, ст.1 (ред. 0т 24.02.2021) - https://www.zakonrf.info/zakon-0-policii/

3. Мантуров Олег Сергеевич, Ганага Виктория Сергеевна Коммуникативные компетенции сотрудников полиции в цифровом пространстве. Полицейская деятельность. 2020. № 5. С. 1-17.

4. Гамезо М.В., Петрова Е.А., Орлова Л.М. Возрастная и педагогическая психология: Учеб. пособие для студентов всех специальностей педагогических вузов. - М.: Педагогическое общество России, 2003. - 512 с.

5. Назаров В.А. Компетентностный подход в профессиональном образовании. Научный альманах. 2016. № 5-2 (19). С. $217-221$

6. Кокоева Р.Т., Хетагов В.К. Профессиональные Компетенции Преподавателя Высшей Школы // Современные проблемы науки и 0бразования. - 2019. № 3.; URL: http://www.science-education.ru/ru/article/view?id=28800 (дата обращения: 04.03.2021).

7. Инновации в образовании / ред. И.В. Сыромятников. - Москва : Современный гуманитарный университет, 2018. - № 4. - 152 с.; URL: https://biblioclub.ru/index.php?page=book\&id=209448. - ISSN 1609-4646. - Текст: электронный.

8. Коротаева М.С. Формирование Профессионально-Значимых Качеств В Подготовке Сотрудников Правоохранительных Органов. В сборнике: Пенитенциарная система и общество: опыт взаимодействия. 2020. С. 280-284

9. Адольф В.А. Избранные труды: сборник научных трудов: в 2 томах / В.А. Адольф. — Красноярск: КГПУ им. В.П. Астафьева, 2020 — Том 1: Профессиональная компетентность педагога — 2020. — 275 c. — Текст: электронный // Лань: электронно-библиотечная система. URL: https://e.lanbook.com/book/151532 (дата обращения: 04.03.2021). 